\title{
IMPLEMENTATION OF DEBT EQUITY RATIO (DER) AND UNDERWRITER'S REPUTATION ON UNDERPRICING DURING INITIAL PUBLIC OFFERING (IPO) ON THE IDX
}

\author{
${ }^{1}$ Kurniawan Prambudi Utomo, ${ }^{2}$ Abdul Rahman \\ ${ }^{1,3}$ Universitas Bina Sarana Informatika \\ ${ }^{2}$ Universitas Sebelas Maret
}

E-mail: kurniawan.kpu@bsi.ac.id

\begin{abstract}
This study is expected to describe a real phenomenon that occurs on the Indonesian stock exchange to determine the direct relationship between the Debtto Equity Ratio (DER) and the Reputation of the Underwriter on the Indonesia Stock Exchange (IDX).

uses qualitative research, namely field observation research by distributing data that has been structured in a structured manner, and collecting information on the IDX, IDX Fact Book, and scientific literature

From 104 companies and there are 96 companies who experience underpricing, Underpricingon the condition of the company selling shares to the public or Initial Public Offering (IPO) in 2018 which is influenced by the reputation of the underwriter, the size of the company.

This study only consists of three variables, Debt to Equity Ratio (DER), Influence, and Reputation of the Underwriter on the Underpricing Phenomenon, while there are many other factors such as stock trivia and e-IPO so that it will be better and meet scientific principles.

Underpricing that occurs in companies conducting IPOs, is mostly avoided by other companies because the funds obtained are not maximally obtained from the initial investment price and are below the market price or stock price in the market
\end{abstract}

Keyword: DER, Underwriter, Underpricing, IDX 


\section{INTRODUCTION}

Capital markets have a function is one of the means to meet the demand and supply of capital. This is where investors make investments by buying securities such as shares issued by companies, according to the concept according to [12] Capital market is a market for a wide range of long, medium and limited financial instruments that can be traded, whether securities, debt securities, equity, mutual funds, derivative instruments and stocks and bonds and others. Capital markets are able to provide both long and short term funding for companies, private and other institutions such as governments, and as a means for financial investment activities [16] states, capital markets are activities undertaken and initiated with the public offering and trading of securities, shares and bonds to public companies issue [15] that the company's performance must show appropriateness, and according to established procedures, so that investment can be interpreted as an activities that place funds in one or more of the assets for a specified period of time in the hopes of obtaining maximum profit, in accordance with the theory of information asymmetry about shares which says that [5] assume the underwriter has excess information in the capital market, while the company has little information so that the underwriter can just determine the price in accordance with interests by reducing the amount of risk if the shares are not all sold, however for companies that issue new shares, they share the ownership rights of the company to the public if the company has issued shares in the capital market and obtained funding from the public. The term known to the public for companies that sell their shares to the public is called going public. Going public is done in order to obtain funds used for business development, improve capital structure, increase investment, pay off debt, and increase capital.

Before the company goes public, the company will first conduct an initial public offering (IPO), which is to sell shares initially in the inaugural market and then shares that can be traded in the capital market, which is usually referred to as the secondary market, [13] explains that where the capital market is the place to sharing which are generally long term and tradable financial instruments, both bonds (bonds), equities (stocks), mutual funds, derivative instruments and other financial instruments required, this is a accordance with the stock can be construed as a sign of ownership of a person or company that has entity rights for the company itself [1]. Conceptually, a stock is a proof of equity participation in a company and with the evidence of such participation the shareholders are entitled to get a share of the proceeds from the company's business [6] explains that Shares are proof of ownership of a person issued by a company in the form of Company. Many things can foster one's interest in the world of capital markets, especially for novice investors who buy initial shares. Shares that have been purchased can provide 
benefits to gain large capital in the form of capital gains, [11] that capitalization gains will be obtained if there is an excess selling price above the purchase price.

However, the results of the study are inconsistent with research conducted by [9] which states that DER has no effect on the level of underpricing. at the closing price of shares on the stock exchange with the price at the time of the initial public offering (IPO) so that the company is believed to be able to smoothly run its business and generate maximum profit. This is seen by investors as a profitable company, so as to reduce the uncertainty of the IPO and cause the level of underpricing to be lower, therefore this research is expected to be able to describe the phenomena originating from DER and win the underwriter from the underpricing phenomenon.

\section{LITERATURE REVIEW AND HYPOTHESES DEVELOPMENT}

Underpricing can occur because of differences in the two mechanisms of determining the price of shares, in determining the price of shares to be sold on the entering into the main market first everything can be determined by the issuer with the underwriter. Underpricing of the initial stock price can be determined in the secondary market due to the difficulty in determining the initial offering price is due to the absence of relevant price information to assess and determine a fair price. This happened because before the initial public offering, can be done at the company shares had never been trading. Determination of the company stock price is an important factor for companies that use the IPO policy, because it for the amount of funds to be gained from related issuers and risks will be borne by underwriter. The company wants to sell its shares at a price high enough for its existence because by selling shares at a high price, it will obtain a large amount of funds. While underwriters with the full commitment guarantor type tend to set the initial usually the stock price is lower than the issuer's expected, as this is in accordance with the concept of the stock price in the main market (IPO) lower than the stock price on the secondary market the first day, there will be a low price this phenomenon in the initial offering, which is called underpricing [7].

Underpricing is a phenomenon where there is a positive difference between the share price in the secondary market generally the stock price occurs when the initial public offering occurred. Besides underpricing can be caused by signals from within the company that are attractive to investors so that investors dare to buy the company's initial shares above the bid price. The purpose of the undewriter is to set the market price to be lower so that the underwriter can emphasize the risk he is enduring if the 
shares offered at the time of the initial public offering are not sold out. After the initial share price has been determined as a result of the issuer's negotiations with the underwriters, then the share price in the secondary market will be determined by the market mechanism that occurs in the stock exchange. Inconsistency regarding underpricing is still considered a problem for researchers, related to what variables affect the underpricing of shares.

By testing the independent variables that are suspected to influence underpicing, including debt equity ratio (DER), and underwriter reputation. The author makes observations and makes the allegation that the higher the DER, the higher the chance of underpricing, because high financial leverage indicates financial risk or the risk of failure of the company to repay loans will be higher, and vice versa, this is in accordance with the statement large DER reflects the relatively high risk of the company, as a result investors tend to avoid shares that have a high DER value shares he owns [14].In a study conducted by [8] states that DER has a positive and significant effect on the level of underpricing of shares, this condition occurs because DER shows the extent to which the company's ability to meet its long-term obligations. The higher the company's DER, the higher the level of underpricing. This shows that companies with lower DER levels (better company quality) will set IPO prices close to intrinsic value, which results in lower underpricing. And conversely, companies with high DER levels (poor company quality) will set IPO prices far below intrinsic value to compensate investors for informational risk. A high DER indicates a financial risk or the risk of a company's failure to repay a loan will be higher, and vice versa. Because the higher the DER of a company, the greater the underpricing.

\section{RESEARCH METHODOLOGY}

In this study using qualitative research with the aim how to determine the relationship between debt to Equity Ratio (DER) effect, and underwriter reputation on the underpricing phenomenon of initial shares on the Indonesia Stock Exchange (IDX) and the causal effects, this type of research is observational research in the field. That has been arranged in a structured manner, the distribution and collection of questionnaires is carried out directly by researchers by means of delivering direct questionnaires and data collection methods through field surveys and the this type of research data used is secondary data obtained from the Indonesia Stock Exchange This research was conducted by collecting indirect information obtained from companies on the IDX, Fact Book, and scientific literature, containing the initial offering price of shares, Debt to Equity Ratio, Company Size, Company Age, which 
has 2016 annual financial statements 2018 which has not been done by previous research, that each company that conducts an IPO under average experiences proven from 104 companies that do IPO until the end of 2018, and there are 96 companies which is only in the process of comparing DER, underwriter and underpricing, so this research is expected to be able to benefit both beginners and old investors in determining global investment choices. This research was conducted in 2019.

\section{RESULTS AND DISCUSSION}

The development of companies conducting IPOs (initial public offering) from 2016 to 2018 has always experienced an increase due to the increasing number of companies that need funds to expand and funds to repay corporate debt. This can be seen from the company's IPO development chart as follows:

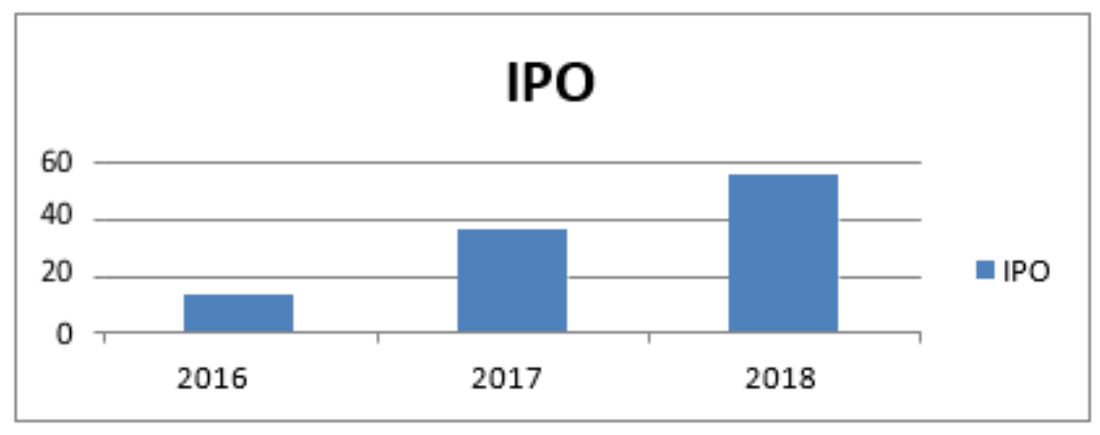

Figure 1. Development of IPO from 2016 - 2018

The development of companies that went public occurred all sectors listed on Indonesia Stock Exchange in Jakarta, during the period 2016 to 2018 moving upward [2]. In addition to the Composite Stock price Index (CSPI) in Indonesia Stock Exchange that reached of the target, the highest number of companies listed this year was the highest. Common phenomena that occur are frequent when an IPO in the capital market is the phenomenon of underpricing and overpricing. [5] explains that underpricing occurs due to the too low IPO share price agreed, on the other hand stock prices in the secondary market have been able to explain a balanced situation.

If the price of an IPO share is lower than the price formed on the secondary market, it can be said that the share price is underpricing. Underpricing events also occur in 
Indonesia, on average companies experience underpricing events at the time of an IPO. While overpricing where the The general stock price in the main market is higher than price of shares in the next market is the secondary market. Many companies experience underpricing when using IPO policies. The number of companies whose shares are experiencing underpricing can besee at the table 1 below [4]:

Table 1. List Underpricing 2016 to 2018

\begin{tabular}{lllll}
\hline & & \multicolumn{3}{l}{ Total } \\
Year & IPO Amount & $\begin{array}{l}\text { Total } \\
\text { Overprincing }\end{array}$ & Total & $\%$ \\
\hline 2016 & 13 & 2 & 11 & 84.6 \\
2017 & 36 & 4 & 32 & 88.9 \\
2018 & 55 & 3 & 52 & 94.5 \\
Total & 104 & 9 & 96 & \\
\hline
\end{tabular}

At the table 1, [3] it can be explaned that each company that conducts an IPO under average experiences proven from 104 companies that do IPO until the end of 2018, and there are 96 companies that experience underpricing or around $89.3 \%$, only $10.7 \%$ who do not experience underpricing and who experience overpricing, and we can also see that the different levels of underpricing each year, this is what makes the writer interested in examining the effect that influence underpricing at time of an initial public offering in Indonesia Stock Exchange.

The underpricing condition is very unfavorable for companies conducting an IPO because the source of funds to maintain and develop a company obtained from an IPO is not maximum, but on the other hand these conditions are beneficial for investors because the IPO provides a positive abnormal return. Investors will have a high connection to a stock because the highly level of underpricing, the higher the core return expected by investors. But otherwise, if there is known overpricing, the investor will definitely lose a lot of money because he does will not receive an initial return. The company owners want to be able to minimize underpricing. There are several the most influencing factor, phenomenon underpricing, which consists of 
financial variables, such as the DER ratio and company size. In addition to financial factors there are also other types of non-financial factors such as underwriter reputation performance, and age of a company.

In generalIf the company debt a high, it means that the company is very dependent on external capital and that is said to be bad and if the DER is high, it meaning that it indicates that the asset of the company financed by the debt are also higher. For creditors, companies have low percentage shows the DER (debt equity ratio) the better. In addition to financial factors as for non-financial factors that cause underpricing, namely the age of the company. Can be explained that the company's age shows it shows that how long the company has been running the ultimately shows the business that it affects explaining experience levels it has in the dealing with show competition and provides more extensive and broader company information than the newly established company. [10] find that the longer a company is established, the underpricing level tends to be lower. Underwriter has the duty to set prices when the issuer offers initial shares and is responsible for the issuer. Underwriter reputation is very important, underwriter with higher will be better known by the market, and the market will trust underwriter with high reputation will not guarantee poor quality companies.

\section{CONCLUSIONS}

From the study above explains that the size of the company a negative influence on the underpricing in the company that indicated an IPO in a certain year. High total assets in the size of the company means that a company is categorized as a large company because the total assets reflect the wealth owned by the company. High total assets also make investors trust and know the long-term prospects of the company so that it becomes one of the choices to invest or invest their capital so that it will minimize underpricing. Then investors or potential decisions of investors in making investment at companies that will finallydid an IPO in addition to considering the reputation of the underwriter and company size because it is proven to have a significant effect on underpricing, investors can also pay attention to other variables, policies such as return on assets (ROA) and return on equity (ROE) to find out the company's impact prospects. for companies that want to carry out an IPO, can consider the size of the company and financial leverage that is proven to affect the level of underpricing.

Considering these factors can optimize the profit potential that will be achieved by companies from IPO activities because the level of underpricing can be reduced. For potential investors, can consider the factor of company size and financial leverage in 
choosing the shares of companies that carry out an IPO to invest. For further research, it can measure the level of underpricing by using a longer period of about 6 months to 1 year after the IPO, this can better reflect the actual market situation. Besides measuring the reputation of the underwriter can be by other methods, namely rating by third parties such as magazines and other credible institutions and can carry out further research on other variables that have the potential to affect the level of underpricing such as the performance of the parent or other companies in the same group and have been listed on the IDX.

\section{LIMITATION AND STUDY FORWARD}

This study only consists of three variables, Debt to Equity Ratio (DER), Influence, and Reputation of the Underwriter on the Underpricing Phenomenon, while there are many other factors such as stock trivia and e-IPO so that it will be better and meet scientific principles.

\section{ACKNOWLEDGMENT}

The researcher would like to thank the Indonesia Stock Exchange Institute for the study and research collaboration and research staff members to collaborate during the research implementation phase, and also thank the University for providing everything for further research, research research, seeking benefits for academics, and the world Banking economics in Indonesia.

\section{REFERENCES}

Budisantoso., Totok., \& Nuritomo., (2018) Banks and Other Financial Institutions Edition, 3 Jakarta, Salemba Empat

Halim, Abdul, (2015) Business Financial Management, Jakarta, Mitra Discourse Media.

Sugiyono, (2016) Management Research Method Bandung, Alfabeta

Ghozali, Imam, (2018) Multivariate Application with IBM SPSS 25 Program Edition 9, Semarang, UNDIP.

G. A. S. Kartika and I. M. P. D. Putra 2017 Underpricing Initial Public Offering Factors in Indonesia Stock Exchange, E-Journal of Udayana 
University Accounting, 19, 220-223

I Putu E, P, P., and Luh K. S., 2017 The Influence of Underwriter Reputation, Company Size, and Industrial Types of Underpricing When IPO in BEI Eud, Management E-Journal, 6 (1), 492-520

A. C. Saputra and I G. N. Suaryana 2016 Influence of Corporate Aging, Company Sizes, Return on Assets and Financial Leverage in Public Offering Underpricing, E-Journal of Udayana University Accounting, 15, 120122

E. Yanti and G. W. Yasa 2016 Go Public Stock Company Underpricing Determinants In 2009-2013, E-Journal of Udayana University Accounting, 16, 244-274

R. Auliya and I. Januarti. 2015 The Influence of Corporate Governance Mechanism on Ipo Underpricing Level, Empirical Study of Companies with an IPO on The Indonesia Stock Exchange In 2009-2014, Diponegoro Journal of Accounting, 4, 1-9

N. Umdiana and D. P. Hapsari. 2016 Analysis of Influence of Clean Cash Flows and Profit Against Share, Accounting Journal, 3 (6), 16-23

S. Octaviani. 2016 Factors Affecting Stock Return on Primary Stock Emissions Accounting Journal, 3, 40-53

I. Syafrida and A. Adib 2015 Performance of Capital Market Related to Changes in Trade and Factory Stock Price Change in Indonesia Stock Exchange, Journal of Accountancy, Finance and Banking,1, 170-177

R. Permatasari and R. W. R. Kusumah 2017 Effect of Return on Assets, PriceEarning Ratio, Company Size, Procentage of Share Offering, and Underwriter Reputation of Underpricing Levels (Journal of Accounting and Business, Widyatama University, 1, 261- 277

I. A. Djashan 2017 Analysis of Factors on Underpricing of Primary Stock, Journal of Business and Accounting, 19, 251-258

K.P. Utomo and Supriyanto 2020 Application of optimal Community Service and Culture Quality in North Bekasi, Economic and Management Journal, 6, 55-66

Republic of Indonesia, Law Number 8 of 1995 concerning Capital Markets. 